PERSPEKTIF, 8 (2) (2019): 45-52

DOI: http://dx.doi.org/10.31289/perspektif.v8i2.2585

PERSPEKTIF

Available online http://ojs.uma.ac.id/index.php/perspektif

\title{
Sejarah Doloksanggul dan Perkembangannya sebagai Ibukota Kabupaten Humbang Hasundutan (2003-2010)
}

\section{The History of Doloksanggul and Its Development as the Capital of Humbang Hasundutan Regency (2003-2010)}

\author{
Lamtagon Aryanto Sigalingging
}

Jurusan Pendidikan Sejarah, Fakultas Ilmu Sosial, Universitas Negeri Medan, Indonesia.

Diterima: Mei 2019; Disetujui: Juni 2019; Dipublish: Juli 2019

\begin{abstract}
Abstrak
Penelitian ini dilaksanakan di Kota Doloksanggul. Untuk memperoleh data yang diperlukan dalam penyusunan dari skripsi ini digunakan metode penelitian lapangan (field research) dengan pendekatan deskriptif kualitatif, dimana data diperoleh dari lapangan yang berhubungan dengan permasalahan penelitian. Data juga diperoleh dari hasil wawancara dengan para tokoh yang mengetahui tentang sejarah dan perkembangan dari Kota Doloksanggul, selain itu data juga diperoleh dari hasil observasi dan dokumentasi. Dari hasil penelitian, peneliti dapat mengetahui mengenai asal nama dan sejarah huta Doloksanggul. Kota Doloksanggul mengalami perkembangan dengan tahapan-tahapan yang sangat panjang yang terbagi dalam 2 periode yaitu antara tahun 2003-2007 dan 2008-2010 yang meliputi perkembangan Doloksanggul di bidang jumlah penduduk, pendidikan, kesehatan dan transportasi. Disamping itu terdapat juga faktor penghambat berkembangnya kota Doloksanggul yang ditinjau dalam berbagai aspek juga seperti jumlah penduduk, pendidikan, kesehatan dan transportasi. Dari keseluruhan hasil penelitian dilapangan diperoleh kesimpulan bahwa perkembangan Doloksanggul terjadi pada awal kota Doloksanggul menjadi ibukota Kabupaten Humbang Hasundutan, yang dapat ditinjau dari berbagai aspek seperti bidang pertumbuhan jumlah penduduk, pendidikan, kesehatan dan transportasi.
\end{abstract}

Kata Kunci: Sejarah, Doloksanggul, Perkembangan, Ibukota Kabupaten Humbang Hasundutan

\begin{abstract}
This research was conducted in the City of Doloksanggul. To obtain the data needed in the preparation of this thesis, a field research method is used with a qualitative descriptive approach, where data is obtained from the field related to research problems. Data were also obtained from interviews with leaders who knew about the history and development of the City of Doloksanggul, in addition data were also obtained from the results of observations and documentation. From the results of the research, researchers can find out about the origin of the name and history of the Doloksanggul. The city of Doloksanggul experienced development with very long stages which were divided into 2 periods, namely between 2003-2007 and 2008-2010 which included the development of Doloksanggul in the area of population, education, health and transportation. Besides that there are also inhibiting factors for the development of the city of Doloksanggul which are reviewed in various aspects as well as population, education, health and transportation. From the overall results of the study in the field it was concluded that the development of Doloksanggul occurred at the beginning of the city of Doloksanggul as the capital of Humbang Hasundutan Regency, which can be viewed from various aspects such as population growth, education, health and transportation.
\end{abstract}

Keywords: History, Doloksanggul, Development, Capital of Humbang Hasundutan Regency

How to Cite: Sigalingging, L.A (2016). Sejarah Doloksanggul dan Perkembangannya Sebagai Ibukota Kabupaten Humbang Hasundutan (2003-2010). PERSPEKTIF, 8 (2): 45-52

*Corresponding author: ISSN 2085-0328 (Print)

E-mail: Lamtangon12 @gmail.com 


\section{PENDAHULUAN}

Doloksanggul adalah wilayah yang berada pada kelembaban rendah, karena berada di kawasan dataran tinggi. Di daerah ini suhu udara cukup dingin, dalam kata lain daerah ini termasuk salah satu daerah yang bercuaca paling dingin di Sumatera Utara. Sacara administrasi Doloksanggul berbatasan dengan: 1) Sebelah timur: Kecamatan Lintong Nihuta; 2) Sebelah barat: Kecamatan Onan Ganjang; 3) Sebelah selatan: Kecamatan Parmonangan; 4) Sebelah utara: Kecamatan Pollung

Sejarah singkat nama Doloksanggul yaitu berasal dari suatu kegiatan masyarakat yang menghuni daerah ini. Kegiatan itu berupa suatu pesta (ulaon), yang mana pesta itu diselenggarakan di suatu daerah yang cukup jauh, bila ditempuh dengan jalan kaki memerlukan waktu setengah hari untuk dapat menempuhnya, dan jalan yang ditempuh harus melalui Doloksanggul. Pada umumnya dalam adat Batak toba, dimana di daerah ini mayoritas dihuni oleh etnis batak toba, kaum ibu harus mengenakan kebaya dan memakai sanggul (konde) untuk menghadiri suatu pesta (ulaon). Hal itu juga sudah dilakukan oleh ibuibu pada masa itu. Ketika mereka menempuh perjalanan menuju pesta itu, mereka kelelahan dan beristirahat di daerah Doloksanggul dan mencopot sanggul tersebut untuk sementara. Sesampainya di pesta mereka menyadari bahwa sanggul mereka ketinggalan di tempat peristirahatannya.

Setelah pesta usai mereka kembali dengan melewati jalan yang sama, tetapi sanggul yang ketinggalan tadi sudah tidak ada lagi di tempat. Di saat itulah mereka memandang (manatap) dari bukit (dolok) kediaman mereka, bahwa tempat itu sangat indah, lama-kelamaan mereka menyukai tempat itu dan membuka lahan pertanian di tempat tersebut. Sehingga dapat diartikan bahwa bukit adalah dolok dan sanggul berasal dari sanggul ibu-ibu yang ketinggalan dan hilang, lalu mereka menamainya DOLOKSANGGUL.

Doloksanggul adalah ibukota Kabupaten Humbang Hasundutan. Humbang Hasundutan dulunya bagian dari daerah Kabupaten Tapanuli Utara. Selama menjadi bagian dari Kabupaten Tapanuli Utara, daerah Humbang ini merupakan salah satu daerah yang masih cukup tertinggal baik dari segi ekonomi dan juga dari segi pemerintahannya, karena pada masa itu mayoritas penduduknya berpenghasilan dari bertani. Maka seiring dengan dikeluarkannya Undang-undang No.22 tahun 1999 yaitu yang berisi tentang otonomi daerah dalam artian daerah itu yang mengurusi daerahnya sendiri bagi setiap daerah di Indonesia. Dengan dikeluarkannya otonomi daerah ini menjadi acuan bagi Humbang Hasundutan untuk memekarkan diri sebagai Kabupaten baru. Dan pada tanggal 28 Juli 2003 menjadi hari resminya Humbang Hasundutan ini menjadi sebagai Kabupaten dan beribukota di Doloksanggul.

Sebagai ibukota Kabupaten Humbang Hasundutan, Doloksanggul berkembang dengan pesat dan menjadi pusat aktivitas dari masyarakat, seperti pusat jalur transportasi, pusat perdagangan (perekonomian) dan juga pusat dari pemerintahan. Padahal bila ditinjau dari segi luas wilayah, Doloksanggul bukanlah daerah yang terluas wilayahnya dibanding Kecamatan lainnya, hanya berada di urutan keempat dari 10 (sepuluh) Kecamatan yang ada di Kabupaten ini. Kesepuluh Kecamatan itu adalah Kecamatan Parlilitan, Pakkat, Tarabintang, Doloksanggul, Pollung, Onan Ganjang, Sijamapolang, Lintong Nihuta, Paranginan dan Kecamatan Bakti Raja. Doloksanggul hanya mempunyai luas wilayah seluas $211,50 \mathrm{Km}^{2}$, atau hanya $9.06 \%$ dari luas wilayah Kabupaten yang luasnya 2335,33 Km². (BPS Humbang Hasundutan dalam Angka 2003).

Doloksanggul resmi menjadi Ibukota Kabupaten Humbang Hasundutan pada tahun 2003. Setelah menjadi ibukota Kabupaten perkembangan Doloksanggul sangat signifikan dan menunjukkan karakteristik menjadi suatu kota, hal ini ditandai dari segi fisik dan nonfisiknya. Dimana dari semenjak menjadi ibukota Kabupaten (2003) sampai sekarang perkembangannya dapat dilihat dari banyaknya bangunan-bangunan besar, gedung-gedung yang rapat dan juga didukung dengan laju pertumbuhan penduduknya yang dari tahun ke tahun semakin padat. Berdasarkan latar belakang diatas maka penulis tertarik untuk melakukan penelitian dengan judul "Sejarah Doloksanggul dan Perkembangannya Sebagai Ibukota Kabupaten Humbang Hasundutan (2003-2010)". 


\section{METODE PENELITIAN}

Metode penelitian merupakan gambaran secara metodologi tentang cara-cara yang digunakan dalam suatu penelitian. Jenis penelitian yang digunakan dalam penelitian ini adalah penelitian lapangan (field research) dengan pendekatan deskriptif kualitatif, dimana sumber data yang diperoleh dari lapangan berhubungan dengan permasalahan penelitian.

Penelitian lapangan yaitu kegiatan penelitian yang dilakukan di lingkungan masyarakat tertentu, baik di lembaga-lembaga dan organisasi-organisasi kemasyarakatan (sosial) maupun lembaga-lembaga pemerintahan. Sedangkan metode diskriptif kualitatif adalah usaha mendiskripsikan atau menggambarkan atau melukiskan fenomena atau suatu keadaan atau peristiwa yang sedang dikaji untuk ditemukan jawabannya dengan sistematis, faktual dan akurat. Untuk memperkuat literatur dilakukan studi pustaka (library research) dengan mengumpulkan literatur maupun referensi yang berkaitan langsung dengan penelitian.

Sumber data dalam penelitian ini terdiri dari 2 (dua) macam yaitu: 1) Data Primer, Data primer adalah sumber data yang diperoleh secara langsung dari penelitian ini, yakni berupa hasil wawancara yang dilakukan dengan tokoh-tokoh masyarakat yang mengetahui mengenai perkembangan Doloksanggul dan berupa dokumen maupun arsip yang berhubungan langsung dengan penelitian ini; 2) Data Sekunder, Data sekunder adalah data yang dapat diperoleh dari keterangan-keterangan yang didapatkan dari literatur-literatur berupa buku, jurnal ilmiah dan juga artikel-artikel yang beredar di situs internet yang berkaitan dengan masalah di dalam penelitian ini.

Untuk mengumpulkan data-data yang dibutuhkan dalam penelitian ini, maka peneliti memilih 3 (tiga) metode, diantaranya: Metode wawancara yaitu melakukan interview dengan orang-orang yang dapat memberikan masukan dan informasi maupun data-data tentang perkembangan Doloksanggul. Observasi yakni pengamatan yang dilakukan di seluruh kawasan Doloksanggul dan Dokumentasi yakni pengumpulan data-data atau informasi yang bersumber dari kepustakaan tertulis atau dokumen-dokumen dan foto dari objek penelitian.

Teknik analisa data yang dipakai dalam penelitian ini adalah teknik analisa data kualitatif yang dinyatakan dalam bentuk uraian atau kalimat yakni dengan membandingkan antara kajian teoritis dengan data penelitian lapangan. Untuk melakukan analisa data dilakukan beberapa tahap, diantaranya: Tahap pertama, membuat daftar pertanyaan (interview guide) dan daftar observasi (observation guide); Tahap kedua, melakukan wawancara dan observasi; Tahap ketiga, menginterprestasi data berdasarkan data primer dan didukung oleh data sekunder (mencocokkan data-data di lapangan dengan literatur yang ada); Tahap keempat, menyimpulkan data dan menuangkannya ke dalam bab pembahasan.

\section{HASIL DAN PEMBAHASAN \\ Latar belakang Kota Doloksanggul Sebagai \\ Ibukota Kabupaten Humbang Hasundutan}

Tapanuli Utara sebagai Kabupaten induk dari Humbang Hasundutan terbentuk berdasarkan Undang Undang Darurat Nomor 7 Tahun 1956 tentang pembentukan daerah otonom kabupaten-kabupaten dalam lingkungan Propinsi Sumatera Utara. Pada masa pemerintahan penjajahan Belanda, salah satu afdeling di wilayah Keresidenan Tapanuli adalah Afdeling Bataklanden dengan ibukota Tarutung terdiri atas lima onder afdeling. Setelah kemerdekaan tepatnya tahun 1947 Kabupaten Tanah Batak menjadi 4 (empat) kabupaten yaitu: 1) Kabupaten Silindung ibukotanya Tarutung; 2) Kabupaten Humbang ibukotanya Dolok Sanggul; 3) Kabupaten Toba Samosir ibukotanya Balige; 4) Kabupaten Dairi ibukotanya Sidikalang.

Pada Tahun 1950 keempat Kabupaten ini dilebur menjadi Kabupaten Tapanuli Utara, seiring dengan terbentuknya Kabupaten Tapanuli Selatan, Tapanuli Tengah, dan Kabupaten Nias. Keadaan ini bertahan hingga tahun 1964, karena pada saat itu Tapanuli Utara dimekarkan dengan terpisahnya Dairi menjadi Kabupaten berdasarkan Undangundang Nomor 15 Tahun 1964 dan selanjutnya berdasarkan Undang-undang Nomor 12 Tahun 1998 terbentuknya Kabupaten Toba Samosir. Kenyataan 
menunjukan bahwa kedua daerah tersebut mengalami perkembangan dalam meningkatkan kesejahteraan masyarakatnya. Berdasarkan faktor sejarah dan keinginan untuk semakin cepat pembangunan dengan pelayanan yang semakin dekat kepada masyarakat maka harapan yang terkandung selama ini mengkristal menjadi usul pembentukan Kabupaten Humbang Hasundutan melalui terbentuknya Panitia Pembentukan Kabupaten Humbang Hasundutan Terbitnya Undang-undang Nomor 22 Tahun 1999 tentang Pemerintah Daerah yang dilengkapi dengan Peraturan Pemerintah Nomor 129 Tahun 2000 tentang Persyaratan Pembentukan dan Kriteria Pemekaran, Penghapusan dan Penggabungan Daerah, menjadi peluang munculnya wacana perlunya usul pemekaran melalui pembentukan Kabupaten.

Berbekal keinginan untuk mendambakan peningkatan kesejahteraan masyarakat, peluang tersebut dimanfaatkan secara tepat oleh masyarakat di wilayah Humbang Hasundutan melalui Panitia Pembentukan Kabupaten Humbang Hasundutan. Ternyata sejalan dengan tuntutan kemajuan jaman mampu menumbuhkan aspirasi masyarakat untuk mengusulkan Pemekaran Kabupaten Tapanuli Utara melalui usul pembentukan Kabupaten Humbang Hasundutan. Aspirasi murni masyarakat tersebut disambut dan difasilitasi oleh pemerintah Kabupaten Tapartuli Utara, serta dukungan DPRD Kabupaten Tapanuli Utara, yang kemudian memperoleh dukungan Gubernur Sumatera Utara dan DPRD Provinsi Sumatera Utara.

Pemerintah Pusat sangat responsif terhadap aspirasi ini karena dalam waktu relatif singkat Tim Terpadu Depdagri, DPOD dan Komisi II DPR-RI melakukan kunjungan dan pertemuan dengan masyarakat se-wilayah Humbang Hasundutan tanggal 5 September 2002 sebagai lanjutan kunjugan Komisi II DPRRI tanggal 29 Juli 2002. Sebagai tindak lanjutnya maka usul pemekaran ini mendapat pembahasan pada Sidang Paripurna DPR-RI yang pada puncaknya melahirkan Uudangundang Nomor 9 Tahun 2003 tentang Pembentukan Nias Selatan, Kabupaten Pakpak Bharat dan Kabupaten Humbang Hasundutan di Provinsi Sumatera Utara. Pada hari Senin tanggal 28 Juli 2003 Kabupaten Humbang Hasundutan diresmikan oleh Menteri Dalam
Negeri RI sekaligus melantik Penjabat Bupati Drs. Manatap Simanungkalit di Kantor Gubernur Sumatera Utara, Medan. (BPS Humbang Hasundutan Dalam Angka 2003).

Kabupaten Humbang Hasundutan diresmikan oleh Menteri Dalam Negeri RI pada tanggal 28 Juli 2003 menurut UU No.9 tahun 2003, sekaligus melantik Penjabat Bupati Drs. Manatap Simanungkalit di Kantor Gubernur Sumatera Utara, Medan. Maka Kabupaten Humbang Hasundutan untuk memulai pemerintahannya harus mempunyai suatu kota administrasi sebagai pusat pemerintahan yang akan dijadikan sebagai ibukota Kabupaten, maka dipilihlah Doloksanggul sebagai ibukotanya karena Kecamatan Doloksanggul memiliki standart minimal untuk dijadikan ibukota Kabupaten dibandingkan Kecamatan lainnya. Dalam undang-undang pembentukan Kabupaten Humbang Hasundutan (Undang undang RI No. 9 Tahun 2003) juga ditegaskan bahwa Ibukota Kabupaten Humbang Hasundutan adalah Kota Doloksanggul. Berkaitan dengan kebijakan tersebut maka perlu adanya tindak lanjut berupa upaya penyiapan Kota Doloksanggul menjadi sebuah ibukota Kabupaten terutama berkaitan dengan pengembangan kawasan perkotaan dimasa datang. Dimasa mendatang Kota Doloksanggul diperkirakan akan terus mengalami perkembangan akibat beban yang harus diemban. Selama ini Kota Doloksanggul hanya berperan sebagai Ibukota Kecamatan. Dengan ditetapkannya Kota Doloksanggul sebagai Ibukota Kabupaten maka secara otomatis sarana dan prasarana yang harus dipersiapkan di Kota Doloksanggul akan semakin besar pula.

\section{Kondisi dan Perkembangan Doloksanggul Tahun 2003-2007}

Setelah Doloksanggul menjadi ibukota Kabupaten Humbang Hasundutan sekaligus ibukota Kecamatan, Doloksanggul mengalami perkembangan yang cukup pesat. Hal ini bisa kita lihat dari perkembangan pesatnya sarana dan prasana di Doloksanggul sebagai kota dan ibukota sebuah Kabupaten. Perkembangan Doloksanggul dapat dilihat dalam tahap pertama (2003-2007) yang meliputi:

Setelah Doloksanggul menjadi ibukota pemerintahan Humbang Hasundutan jumlah penduduk di Doloksanggul pada awalnya 
memiliki populasi yang cukup banyak. Karena polulasinya penduduk yang cukup banyak ini, sehingga mendorong Doloksanggul untuk berkembang dan membenahi dirinya untuk lebih lengkap juga untuk mewujudkan tersedianya kemudahan dalam sarana dan prasana sebuah perkotaan disamping sebagai sebuah ibukota Kabupaten. Penduduk Doloksanggul bukan saja dari kota tersebut tersebut tetapi berasal dari luar kota Doloksanggul juga yang ingin mencari penghidupan di kota tersebut, sehingga jumlah penduduk terus bertambah bukan dari angka kelahiran tapi juga dari pendatang-pendatang. Jumlah penduduk mengalami pertambahan sehingga mendorong terjadinya perkembangan, hal ini selaras dengan peningkatan sarana dan prasarana kota Doloksanggul yaitu seperti sarana dan prasarana pendidikan, kesehatan dan tranportasi.

Pada awal Doloksanggul menjadi ibukota pemerintahan Humbang Hasundutan sarana pendidikan di Doloksanggul sudah mulai lengkap terdiri dari tingkatan SD sampai SMA, jumlahnya dari pada sekolah-sekolah itu sudah cukup memadai. Siswa-siswa dari sekolah tersebut bukan hanya berasal dari Doloksanggul saja tetapi berasal dari luar kota Doloksanggul juga dan jumlah dari pada siswasiswa sekolah tersebut terus bertambah, sehingga pembangunan sekolah-sekolah juga terus dilakukan.

Jumlah sarana pendidikan mengalami perkembangan, hal ini dapat dilihat dari pertambahan sarana sekolah. Perubahan jumlah sarana pendidikan di Doloksanggul diikuti juga dengan meningkatnya jumlah siswa yang ingin bersekolah, karena itu jumlah sarana pendidikan disesuaikan dengan jumlah siswa sehingga anak-anak yang ingin bersekolah dapat tertampung seluruhnya.

Pada awal Doloksanggul menjadi ibukota pemerintahan Humbang Hasundutan, sarana bidang kesehatan di Doloksanggul sudah terdapat rumah sakit dan sarana kesehatan lainnya antara lain puskesmas, pustu dan posyandu. Dengan sudah adanya pembangunan rumah sakit dan sarana kesehatan lainnya, sehingga masyarakat tidak mengalami kesulitan dalam konsultasi dan perawatan kesehatan.

Jumlah sarana kesehatan mengalami perkembanga. Perubahan jumlah sarana kesehatan di Doloksanggul diikuti juga dengan meningkatnya jumlah calon pasien yang berobat ke rumah sakit dan pusat kesehatan lainya, karena itu jumlah sarana kesehatan terus disesuaikan dengan kebutuhan akan pusat-pusat kesehatan sehingga penduduk yang ingin berobat dapat dilayani seluruhnya.

\section{Perkembangan dalam bidang transportasi}

Pada saat Doloksanggul menjadi ibukota sebuah Kabupaten, sarana transportasi sudah dengan mudah didapat, seperti sepeda motor, bus-bus maupun angkutan umum yang sudah cukup ramai. Angkutan umum serta angkutan pribadi sudah hilir mudik dari kota Doloksanggul atau melintasi kota ini. Sarana tranportasi ini digunakan untuk memperlancar kegiatan sehari-hari dan juda mempermudah menuju ibukota Kabupaten atau propinsi. Hal ini juga yang mendorong Doloksanggul cepat berkembang. Pada saat ini sarana jalan sudah cukup memadai yang dilalui kendaraan roda empat dan juga roda yang cukup ramai, sehingga hampir 24 jam selalu dilalui oleh kendaraan bermotor. Faktor yang mendorong bertambahnya sarana transportasi khususnya angkutan umum adalah bertambahnya jumlah penduduk. Hal ini bisa kita lihat bahwa mobil bus dan sepeda motor yang mengalami perkembangan pada tahun 2007.

Jumlah sarana tranportasi mengalami perkembangan, hal ini dapat dilihat dari pertambahan sarana transportasi di akhir tahun 2007. Perubahan pertambahan jumlah sarana tranportasi di Doloksanggul didukung juga dengan meningkatnya jumlah penduduk, kemudian disesuaikan dengan kebutuhan akan angkutan umum, sehingga penduduk yang ingin melakukan mobilitas dapat dilayani seluruhnya.

Agar mobilitas penduduk dapat berjalan lancar, maka yang dibutuhkan sarana tranportasi yaitu angkutan umum maupun pribadi dan juga prasarana tranportasi yaitu jalan. Jalan merupakan prasarana pengangkutan darat yang penting untuk memperlancar dan mendorong kegiatan perekonomian. Makin meningkatnya pembangunan dan perekonomian disertai tuntutan zaman, maka diperlukan peningkatan pembangunan jalan untuk memudahkan atau memperlancar lalu lintas dalam pengankutan barang maupun manusia dari daerah ke 
daerah lain serta mempercepat akomodasi bagi daerah-daerah yang terisolisir.

Jumlah prasarana tranportasi tidak mengalami perubahan atau pertambahan, hal ini dapat dilihat dari tabel prasarana transportasi di akhir tahun 2007. Perubahan prasarana tranportasi di Doloksanggul yang tidak mengalami perubahan disebabkan oleh konsentrasi pada perbaikan dan perluasan jalan lintas di Doloksanggul agar lebih baik, karena itu jumlah prasarana tranportasi terus disesuaikan dengan kebutuhan akan mobilitas yang lebih baik.

\section{Kondisi dan Perkembangan Doloksanggul tahun 2008-2010}

Perkembangan Jumlah penduduk di Doloksanggul pada awalnya memiliki populasi yang cukup banyak, sehingga mendorong sarana dan prasarana untuk membenahi dirinya menjadi lebih lengkap. Tersedianya kemudahan dalam sarana dan prasana sebuah perkotaan sebagai sebuah ibukota kabupaten dititikberatkan dengan jumlah penduduk yang terus bertambah. Pada tahun 2008 dan 2009 jumlah penduduk di Doloksanggul sudah mencapai 37.045 jiwa dan pada tahun 2010 mengalami juga peningkatan yang signifikan.

Jumlah penduduk mengalami pertambahan sehingga mendorong pembangunan seperti sarana dan prasarana pendidikan, kesehatan dan tranportasi.

Pada periode ini bidang pendidikan sudah mulai berkembang yang terdiri dari tingkatan SD sampai SMA, jumlah sekolahsekolah ini sudah bertambah tetapi kurang memadai. Banyak siswa-siswa dari sekolah tersebut bukan hanya berasal dari luar kota Doloksanggul juga dan jumlah dari pada siswasiswa sekolah tersebut terus bertambah, sehingga pembangunan sekolah-sekolah juga harus terus dilakukan.

Jumlah sarana pendidikan mengalami pertambahan, hal ini dapat dilihat dari pertambahan sarana sekolah. Perubahan jumlah sarana pendidikan di Doloksanggul pada periode ini masih belum diikuti dengan meningkatnya jumlah siswa yang ingin bersekolah, karena itu jumlah sarana pendidikan harus disesuaikan dengan jumlah siswa sehingga anak- anak yang ingin bersekolah dapat tertampung seluruhnya.
Sarana bidang kesehatan di Dolosanggul sudah lengkap, hal ini dapat dilihat dari sudah adanya rumah sakit dan sarana kesehatan lainnya antara lain puskesmas, pustu dan posyandu, sehingga penduduk kota Doloksanggul dalam bidang kesehatan dapat terlayani dengan maksimal.

Jumlah sarana kesehatan mengalami pertambahan, hal ini dapat dilihat dari pertambahan sarana kesehatan yaitu posyandu. Perubahan jumlah sarana kesehatan di Doloksanggul diikuti juga dengan meningkatnya jumlah calon pasien yang berobat ke rumah sakit dan pusat kesehatan lainya, karena itu jumlah sarana kesehatan harus terus disesuaikan dengan kebutuhan akan pusat-pusat kesehatan sehingga penduduk yang ingin berobat dapat dilayani dengan maksimal.

Sarana tranportasi berfungsi untuk menunjang dan memudahkan lancarnya akomodasi untuk kegiatan sehari-hari. Selain itu juga untuk mempercepat menuju ibukota Kabupaten atau propinsi. Pada saat ini sarana jalan sudah cukup memadai yang dilalui oleh kendaraan roda empat dan kendaraan roda dua, hingga hampir 24 jam ini selalu ramai dan lalulalang dilalui oleh kendaraan. Fasilitas transportasi mengalami perkembangan yang pesat, yang bisa kita lihat dari jumlah kendaraan dan jenisnya.

Jumlah sarana tranportasi mengalami perkembangan yang cukup pesat, hal ini dapat dilihat dari pertambahan sarana transportasi di tahun 2008 masih berjumlah 718 sementara di tahun 2009 dan tahun 2010 mengalami peningkatan, hingga berjumlah ribuan. Perubahan pertambahan jumlah sarana tranportasi di Doloksanggul didukung juga dengan meningkatnya jumlah penduduk, karena itu jumlah sarana tranportasi terus disesuaikan dengan kebutuhan akan angkutan umum, sehingga penduduk yang ingin melakukan mobilitas dapat dilayani seluruhnya.

\section{Faktor-Faktor Penghambat Perkembangan Kota Doloksanggul.}

Dalam bidang kependudukan salah satu faktor penghambat pembangunan kota yaitu rendahnya kuantitas dan kualitas SDM, khususnya pada usia produktif yang dapat menghambat pembangunan fisik. Rendahnya 
kualitas SDM, merupakan tantangan untuk tetap melibatkan masyarakat lokal dalam pengembangan kegiatan ekonomi perkotaan. Selain itu belum maksimalnya perencanaan maupun pelaksanaan penyuluhan pemerintah daerah untuk peningkatan produktifitas penduduk.

Masalah yang dihadapi dalam bidang pendidikan, erat hubungannya dengan masalah sumber daya manusia. Dimana mereka yang sudah berpendidikan tinggi seperti S1 dan S2 banyak yang bekerja di luar daerah atau propinsi. Hal ini dikarenakan kurangnya lapangan pekerjaan dan mereka juga menganggap tinggal di Doloksanggul kurang memberikan apa-apa, baik itu materi maupun pengalaman. Meskipun begitu masih ada dari mereka yang mau bekerja yang membangun Doloksanggul walaupun hanya sedikit jumlahnya, selain itu keterbatasan fasilitas atau sarana dan prasarana pendidikan yang ada di Doloksanggul seperti fasilitas untuk perguruan tinggi belum ada. Sehingga mendorong mereka keluar daerah untuk melanjutkan sekolah atau studinya ke jenjang yang lebih tinggi.

Adapun faktor penghambat dalam bidang kesehatan yaitu belum terlaksananya secara maksimal akan penyuluhan kesehatan kepada masyarakat Doloksanggul belum maksimal. Selain itu sarana kesehatan seperti puskesmas masih perlu ditambah jumlahnya.

Masalah yang dihadapi dalam bidang transportasi ialah prasarana transportasi yaitu jalan. Minim Jalan-jalan yang menghubungkan kota Doloksanggul dengan kota-kota disekitarnya seperti jalan yang menghubungkan dengan Pakkat, Siborongborong, Sidikalang masih banyak dalam kondisi rusak. Kemudian pola jaringan jalan yang tidak terintegrasi tidak tertata dengan baik. Untuk menunjang sarana perangkutan yang ada pada kota Doloksanggul sekarang ini perlu dibangun terminal, mengingat perkembangan kota saat ini sudah mulai berkembang. Untuk sekarang ini terminal tersebut belum ada, para pengendara masih memarkirkan kenderaan masing-masing secara sembarangan dan juga pada lokasilokasi tertentu sehingga sering mengakibatkan kemacetan terutama pada pusat kota. Sehingga tidak adanya terminal merupakan salah satu faktor penghambat pembangunan Kota

\section{Doloksanggul}

sendiri

dalam

bidang transportasi.

\section{SIMPULAN}

Dimasa

mendatang

Kota

Doloksanggul diperkirakan akan terus mengalami perkembangan akibat beban yang harus diemban. Selama ini Kota Doloksanggul hanya berperan sebagai Ibukota Kecamatan. Dengan ditetapkannya Kota Doloksanggul sebagai Ibukota Kabupaten, maka secara otomatis sarana dan prasarana yang harus dipersiapkan di Kota Doloksanggul akan semakin besar pula. Adapun faktor-faktor yang mendukung Kecamatan Doloksanggul sebagai ibukota Kabupaten Humbang Hasundutan, yaitu faktor letak geografis, fasilitas ekonomi (sektor industri, perdaganghan jasa, pertanian, peternakan, laju pertumbuhan ekonomi), prasarana umum (fasilitas pendidikan, kesehatan, peribadatan, perkantoran dan pemerintahan, kondisi bangunan dan lingkungan perumahan), fasilitas transportasi dan utalitas kota.

Perkembangan Kota Doloksanggul yang dibagi dalam dua periode yaitu periode pertama dari tahun 2003-2007 dan periode kedua dari tahun 2008-2010, meliputi jumlah penduduk, bidang pendidikan, kesehatan dan bidang transportasi. Selain faktor-faktor pendukung perkembangan kota, ada juga faktor-faktor penghambat, diantaranya kurangnya fasilitas dalam bidang jumlah penduduk, bidang pendidikan, kesehatan dan bidang transportasi.

\section{DAFTAR PUSTAKA}

Adsasmita, R. (2006). Pembangunan Pedesaan dan Perkotaan. Pustaha Graha Ilmu

Bintarto. (1993). Perkembangan dan Pertumbuhan Daerah.

Bintarto. (1997). Pengantar Geografi Kota: Yogyakarta

Biro Pusat Statistik. (2003). Humbang Hasundutan Dalam Angka

Biro Pusat Statistik. (2006). Kecamatan Doloksanggul Dalam Angka

Biro Pusat Statistik. (2007). Kecamatan Doloksanggul Dalam Angka 
Lamtagon Aryanto Sigalingging, Sejarah Doloksanggul dan Perkembangannya Sebagai Ibukota

Biro Pusat Statistik. (2009). Kecamatan Doloksanggul Dalam Angka

Biro Pusat Statistik. (2010). Kecamatan Doloksanggul Dalam Angka

Biro Pusat Statistik.. (2008). Kecamatan Doloksanggul Dalam Angka

Biro Pusat Statistik.. (2010). Humbang Hasundutan Dalam Angka

Castles, L. (2001). Kehidupan Politik Suatu Keresidenan Di Sumatra: Tapanuli 19151940. Jakarta: Kepustakaan Populer Gramedia (KPG)

Daldjoeni, N. (1985). Seluk Beluk Masyarakat Kota. Bandung: Penerbit Alumni

Fakultas ilmu Sosial. (2007). Buku Pedoman Penulisan Sikripsi Dan Proposal Penelitian.

http://beeingawinner.blogspot.com/2011/01/secu il-cerita-dari-dolok-sanggul.html

http://id.wikipedia.org/wiki/Dolok_Sanggul,_Hum bang_Hasundutan

http://my.opera.com/SupandiMarbun/blog/.

Hutagalung, W.M. (1991). Pustaha Batak. Tulus Jaya

Koestoer (dkk). 2001. Dimensi Keruangan Kota. Jakarta: UI Press

Kuntowijoyo. (1994). Metodologi Sejarah. Yogyakarta: PT. Tiara Wacana Yogya
Kuntowijoyo. (2003). Metodologi Sejarah. Yogyakarta: PT. Tiara Wacana Yogya

Kuntowijoyo. (2005). Pengantar Ilmu Sejarah. Yogyakarta: Benteng Pustaka

Menno, S dan Alwi, M. (1992). Antropologi Perkotaan. Jakarta: Rajawali Press

Pemerintah Kabupaten Humbang Hasundutan. (2004). Profil dan Potensi Daerah

Poedarminta. (1986). Perkembangan Desa Kota. Yogyakarta: Rineka Cipta

Poerwadarminta. W.J.S. (1983). Kamus Umum Bahasa Indonesia. Pusat Pembinaan dan Pengembangan Bahasa Debdikbud. Jakarta

Silaban, J. (2008). Terbentuknya Kabupaten Humbang Hasundutan (Analisis Sejarah). Sikripsi. Fis Unimed

Suharsimi, A. (2006). Prosedur Penelitian. Jakarta: PT. Rineka Cipta

Sujanto, A. (1985). Psikologi Perkembangan. Jakarta: Aksara Baru

Undang-Undang Republik Indonesia NO.22 Tahun 1999. Himpunan Pengaturan Tentang pemerintahan Daerah. Jakarta: Djambatan

www.humbanghasundutankab.go.id

Yuswita, T. (2008). Pertumbuhan Dan Perkembangan Galang Kota dari Tahun 19201980. Sikipsi. Fis Unimed. 